Supporting Information

\title{
A Simple Method for Proper Analysis of FRET Sensor Titration Data and Intracellular Imaging Experiments Based on Isosbestic Points
}

\author{
Anne M. Hessels and Maarten Merkx* \\ Laboratory of Chemical Biology and Institute of Complex Molecular Systems (ICMS), \\ Department of Biomedical Engineering, Eindhoven University of Technology, Eindhoven, \\ The Netherlands.
}

* corresponding author: m.merkx@ @ tue.nl 


\section{Contents:}

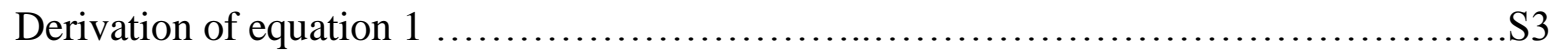

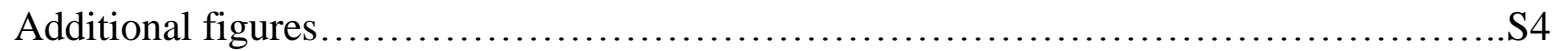

Additional tables.................................................................... 10

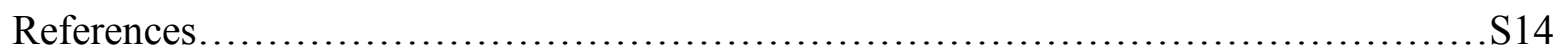




\section{Derivation of equation 1}

Pomorski et al derived the following equation to determine the correct $K_{\mathrm{d}}$ value when using ratiometric titration data with a Hill coefficient of 1 (equation 8 in Pomorski et al (2013) Anal. Chem 85, 11479-11486) :

$R_{1 / 2}=\frac{I_{1 b} x+I_{1 u} K_{d}}{I_{2 b} x+I_{2 u} K_{d}}$

Where $I_{1 b}$ is the intensity at $\lambda_{1}$ of the bound sensor, $I_{1 u}$ is the intensity at $\lambda_{1}$ of the unbound sensor, $I_{2 b}$ is the intensity at $\lambda_{2}$ of the bound sensor, $I_{2 u}$ is the intensity at $\lambda_{2}$ of the unbound sensor, $\mathrm{x}$ is the concentration of the ligand, $K_{\mathrm{d}}$ is the dissociation constant.

If $\lambda_{2}$ is the isosbestic wavelength, then

$I_{2 b}=I_{2 u}=I_{2}$

We can therefore start rewriting the Pomorski equation as follows

$$
\begin{aligned}
& R_{1 / 2}=\frac{I_{1 b} x+I_{1 u} K_{d}}{I_{2}\left(x+K_{d}\right)} \\
& R_{1 / 2}=\frac{\left(I_{1 b} / I_{2}\right) x+\left(I_{1 u} / I_{2}\right) K_{d}}{\left(x+K_{d}\right)} \\
& R_{1 / 2}=\frac{R_{1 / 2, b} x+R_{1 / 2, u} K_{d}}{\left(x+K_{d}\right)} \\
& R_{1 / 2}=\frac{R_{1 / 2, b} x}{\left(x+K_{d}\right)}+\frac{R_{1 / 2, u} x}{\left(x+K_{d}\right)} \\
& R_{1 / 2}=\frac{R_{1 / 2, b} x}{\left(x+K_{d}\right)}+\frac{\left(x+K_{d}\right) R_{1 / 2, u}-R_{1 / 2, u} x}{\left(x+K_{d}\right)} \\
& R_{1 / 2}=\frac{\left(R_{1 / 2, b}-R_{1 / 2, u}\right) x}{\left(x+K_{d}\right)}+R_{1 / 2, u} \\
& \equiv R=\frac{\left(R_{100 \%}-R_{0 \%}\right)\left[Z n^{2+}\right]}{\left(K_{d}+\left[Z n^{2+}\right]\right)}+R_{0 \%}
\end{aligned}
$$


A

CALWY-4

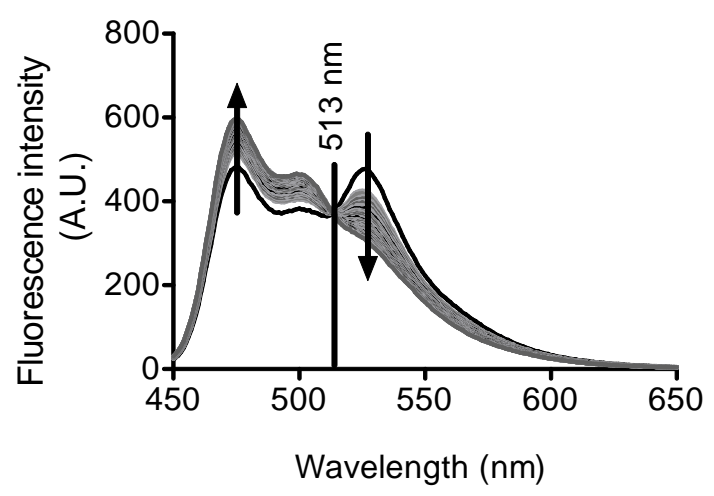

$C$

eZinCh-2

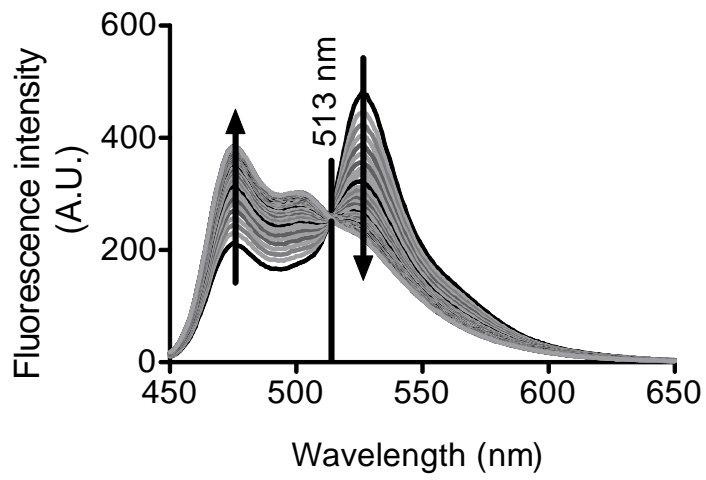

$E$

MagFRET-1

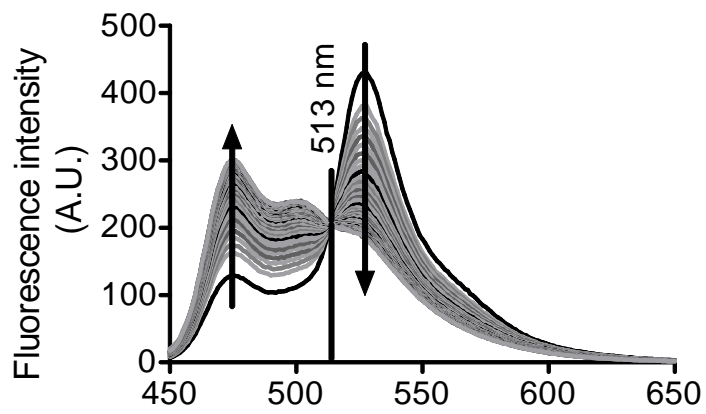

Wavelength $(\mathrm{nm})$
B

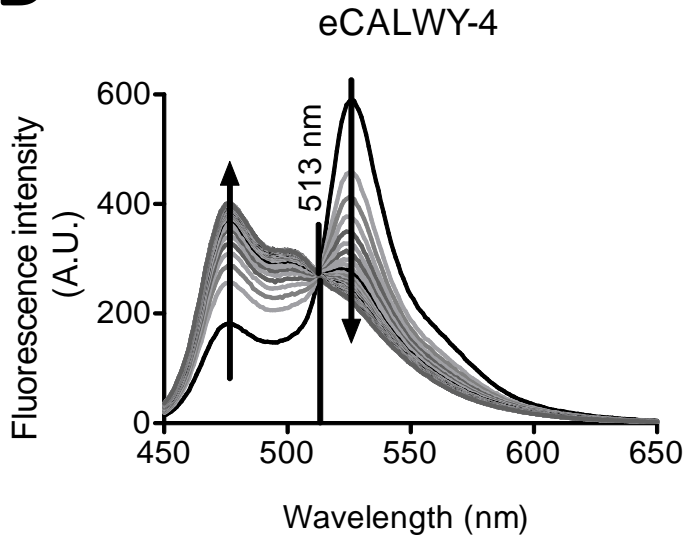

Cer-L9-Cit-2His

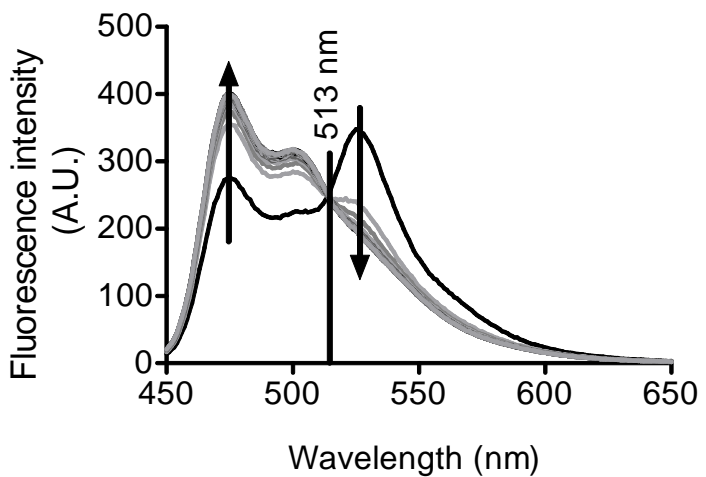

BAS-1

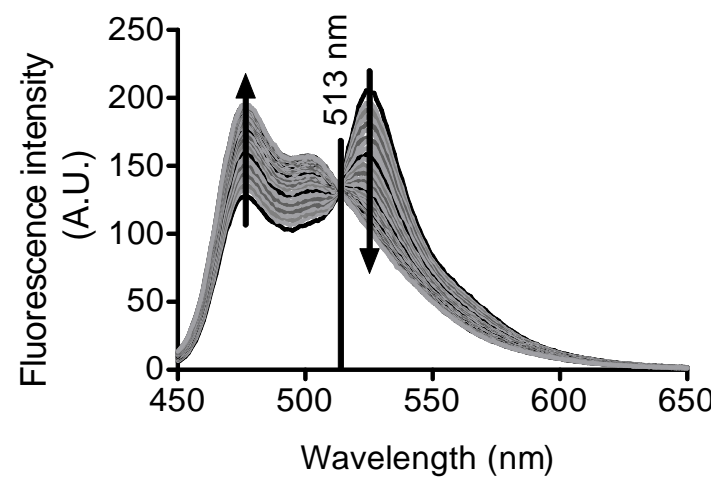

Figure S1: Emission spectra of six different FRET sensors monitored in time following treatment with 0.03U proteinase K, upon excitation at $420 \mathrm{nM}$. Treatment with proteinase $\mathrm{K}$ cleaves the flexible linkers in these sensor constructs, but does not affect the fluorescent domains (CALWY-4 (A), eCALWY-4 (B), eZinCh-2 (C), Cer-L9Cit-2His (D), MagFRET-1 (E) and BAS-1 (F)). For MagFRET-1 and BAS-1 measurements were performed using $\sim 1 \mu \mathrm{M}$ protein in $150 \mathrm{mM}$ HEPES, $100 \mathrm{mM} \mathrm{NaCl}, 10 \%(\mathrm{v} / \mathrm{v})$ glycerol and $0.01 \%(\mathrm{v} / \mathrm{v}) \mathrm{Tween}, \mathrm{pH} 7.1$ at $20{ }^{\circ} \mathrm{C}$. The same buffer with addition of $1 \mathrm{mM}$ DTT and $1 \mathrm{mM}$ EDTA was used for the $\mathrm{Zn}^{2+}$ binding FRET sensors (e)CALWY-4, eZinCh-2 and Cer-L9-Cit-2His. Proteinase K cleavage was monitored by recording emission spectra between $450-650 \mathrm{~nm}$ at an interval of $45 \mathrm{~s}$ for a period of 20 minutes. 

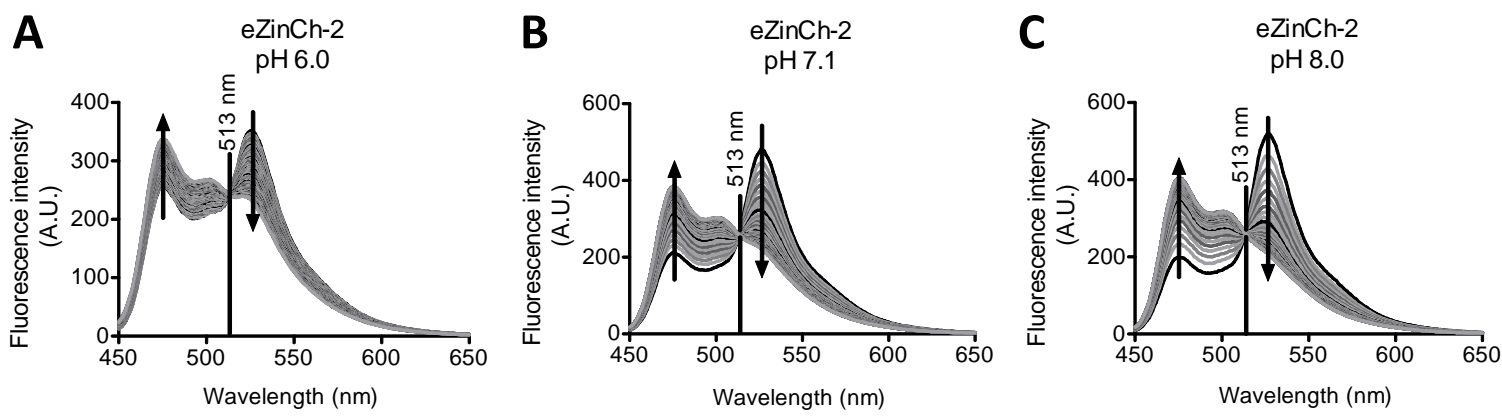

Figure S2: Change in emission spectra of eZinCh-2 upon treatment proteinase K (0.03 U) at pH 6.0 (A), 7.1 (B) and 8.0 (C) upon excitation at $420 \mathrm{~nm}$. Treatment with proteinase $\mathrm{K}$ cleaves the flexible linkers in these sensor constructs, but does not affect the fluorescent domains. Measurements were performed using $\sim \mu \mathrm{M}$ protein in $150 \mathrm{mM}$ MES( pH 6.0), $150 \mathrm{mM}$ HEPES (pH 7.1) or 50 mM This (pH 8.0), 100 mM $\mathrm{NaCl}, 10 \%(\mathrm{v} / \mathrm{v})$ glycerol, $0.01 \%(\mathrm{v} / \mathrm{v})$ Tween, $1 \mathrm{mM}$ DTT and $1 \mathrm{mM}$ EDTA at $20{ }^{\circ} \mathrm{C}$. Proteinase $\mathrm{K}$ cleavage was monitored by recording emission spectra between $450-650 \mathrm{~nm}$ at an interval of $45 \mathrm{~s}$ for a period of 20 minutes.

SF 
A

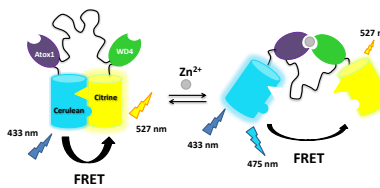

C

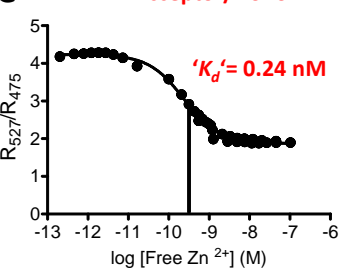

E

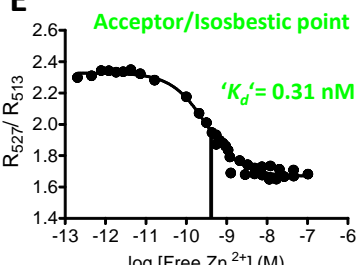

B $\mathrm{pH} 7$.

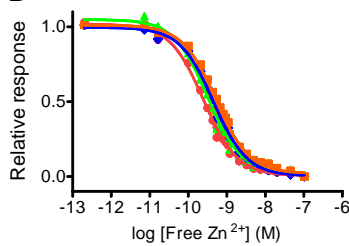

D Donor/Acceptor

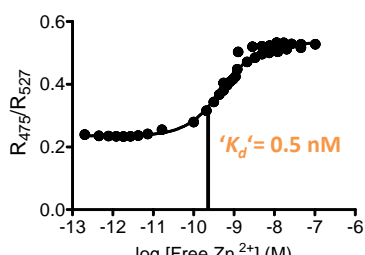

$\log \left[\right.$ Free $\left.\mathrm{Zn}^{2+}\right](\mathrm{M})$

F

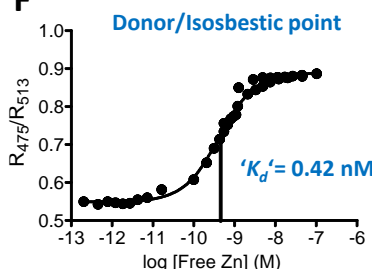

Figure S3 (A) Schematic representation of eCALWY-4. Atox1 and WD4 were used as metal binding domains. Introduction of mutations $\mathrm{S} 208 \mathrm{~F}$ and V224L on both cerulean and citrine induced complex formation between the fluorescent domains in the absence of $\mathrm{Zn}^{2+}$. $\mathrm{Zn}^{2+}$ binding to Atox 1 and WD4 results in an decrease in energy transfer between cerulean and citrine. (B) Normalized ratiometric response as a function of $\mathrm{Zn}^{2+}$ concentration at $\mathrm{pH}$ 7.1. Red circles represent the acceptor/donor emission ratio, green triangles the acceptor/isosbestic point emission ratio, blue diamond's represents the donor/isosbestic point ratio and orange squares the donor/acceptor ratio. The solid lines represent a fit assuming a 1:1 binding event, with corresponding colors (red, green, blue and orange). (C - F) $\mathrm{Zn}^{2+}$ titration of eCALWY-4 at $\mathrm{pH}$ 7.1, showing the emission ratio of acceptor/donor (C), donor/acceptor (D), acceptor/isosbestic point (E) and donor/isosbestic point (F) as a function of $\mathrm{Zn}^{2+}$ concentration. To obtain picomolar to micromolar free $\mathrm{Zn}^{2+}$ concentrations, different buffering systems were used (Table S6). Solid lines represent a fit assuming a 1:1 binding event, yielding $K_{d}$ 's of $0.24 \mathrm{nM}$ (acceptor/donor), $0.5 \mathrm{nM}$ (donor/acceptor), $0.31 \mathrm{nM}$ (acceptor/isosbestic point) and $0.42 \mathrm{nM}$ (donor/isosbestic point).Vertical lines represent the point where the sensors are half saturated. Measurements were performed in $150 \mathrm{mM}$ HEPES (pH 7.1), $100 \mathrm{mM} \mathrm{NaCl}, 10 \%$ (v/v) glycerol, $0.01 \%$ Tween and $1 \mathrm{mM} \mathrm{DTT}$ at $20{ }^{\circ} \mathrm{C}$ 
A

$\mathrm{pH} 6.0$

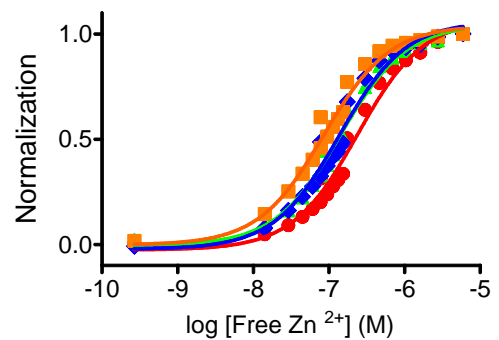

B

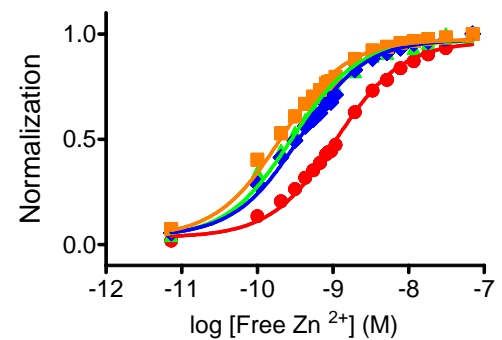

C

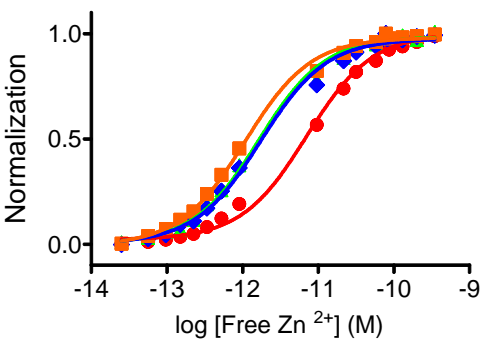

Figure S4: Normalized ratiometric response of eZinCh-2 as a function of $\mathrm{Zn}^{2+}$ concentration at pH 7.1 (A), 6.0 (B) and 8.0 (C). Red circles represent the acceptor/donor emission ratio, green triangles the acceptor/isosbestic point emission ratio, blue diamonds the donor/isosbestic point ratio and orange squares the donor/acceptor ratio. The solid lines represent a fit assuming a 1:1 binding event, with corresponding colors. The $\mathrm{K}_{\mathrm{d}}$ 's are listed in Table 1 . Various buffering systems were used to obtain the depicted free $\mathrm{Zn}^{2+}$ concentrations (Table $\mathrm{S} 5-\mathrm{S} 7$ ). Measurements were performed in $150 \mathrm{mM}$ MES (pH 6.0), $150 \mathrm{mM} \mathrm{HEPES} \mathrm{(pH} \mathrm{7.1)} \mathrm{or} 50 \mathrm{mM}$ Tris (8.0) and 100 mM NaCl, 10\% (vol/vol) glycerol, $0.01 \%$ Tween and $1 \mathrm{mM}$ DTT at $20^{\circ} \mathrm{C}$. 

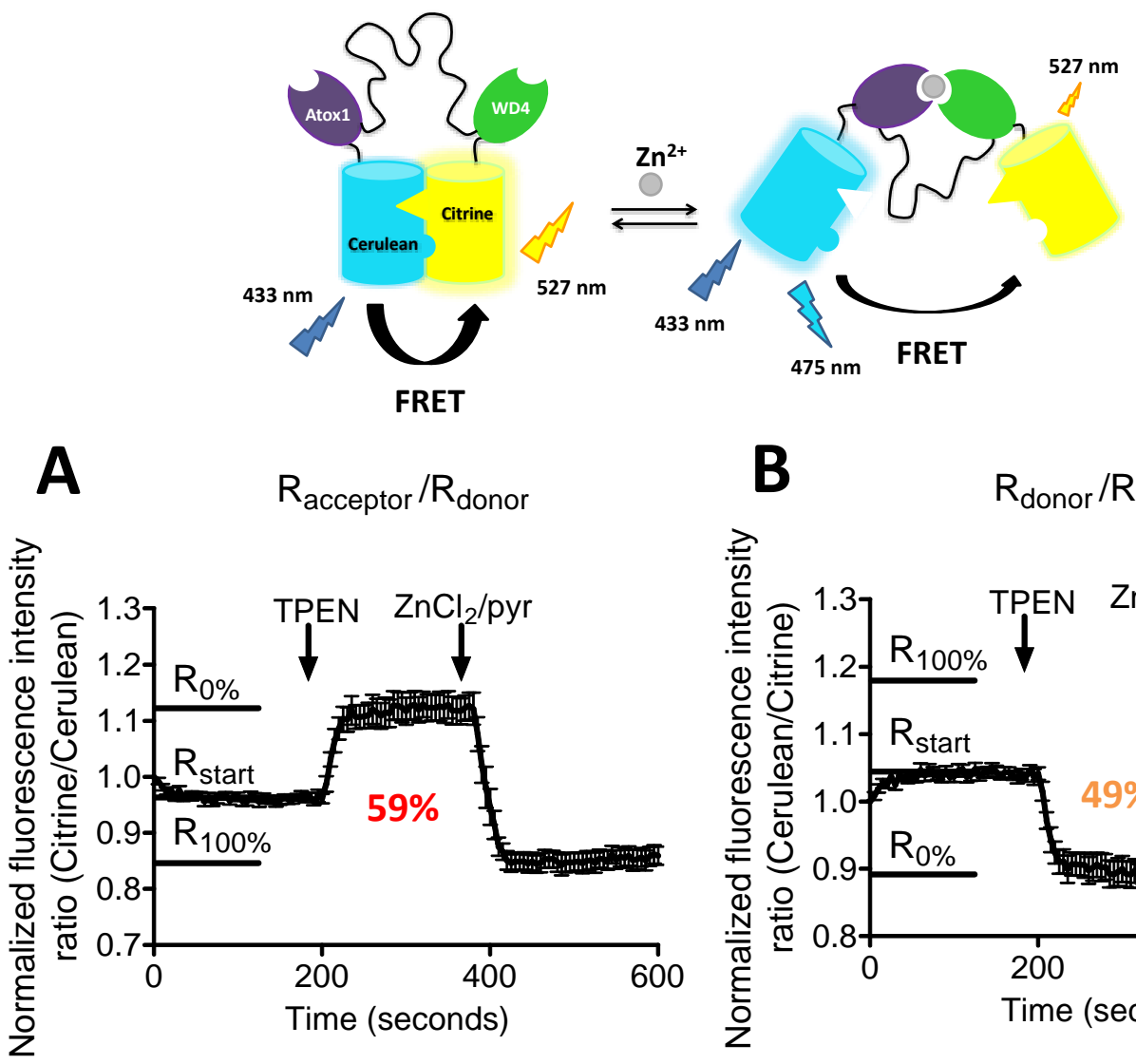

B $\quad \mathrm{R}_{\text {donor }} / \mathrm{R}_{\text {acceptor }}$
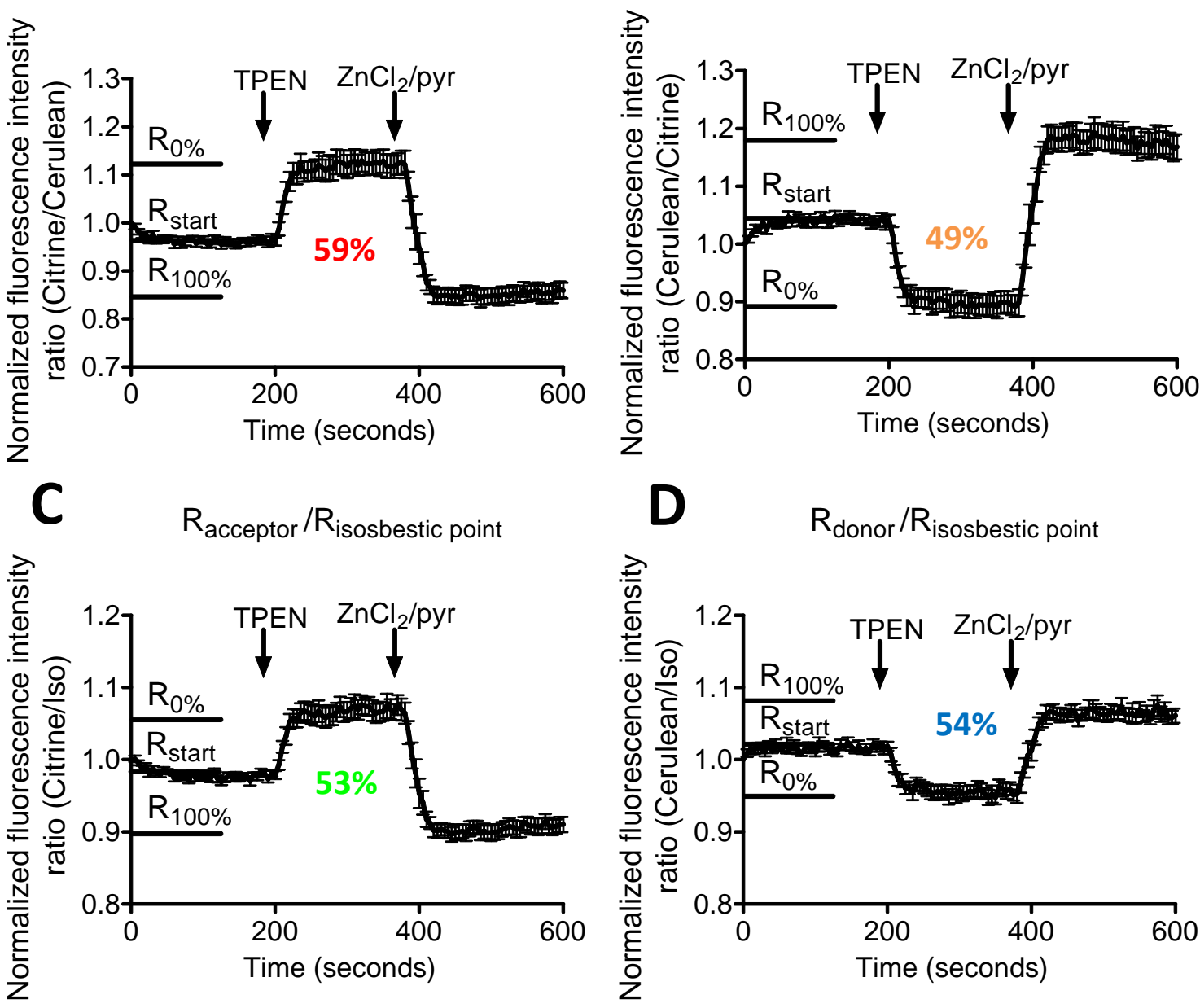

Figure S5: Determination of free cytosolic $\mathrm{Zn}^{2+}$ concentrations in HeLa cells using eCALWY-4 (A - D). For each sensor the response of HeLa cells to the addition of $50 \mu \mathrm{M}$ TPEN, followed by excess $\mathrm{Zn}^{2+}$ and pyrithione (100 $\mu \mathrm{M} \mathrm{ZnCl} / 2 / 5 \mathrm{M}$ pyrithione), was monitored by plotting four different emission ratios, acceptor/donor (A) donor/acceptor (B) acceptor/isosbestic point (C) and donor/isosbestic point (D). The mean sensor occupancy was determined from each plot based on the emission ratio at the start of the experiment $\left(\mathrm{R}_{\text {start }}\right)$, the emission ratio in the presence of TPEN $\left(\mathrm{R}_{0 \%}\right)$ and the emission ratio in the presence of excess $\mathrm{Zn}^{2+}\left(\mathrm{R}_{100 \%}\right)$. The occupancy for each plot is listed in Table S3 (calculated using equation 2). All traces represent the average of at least four cells normalized at $t=0 \mathrm{~s}$. Error bars represent the standard error of the mean (SEM). 

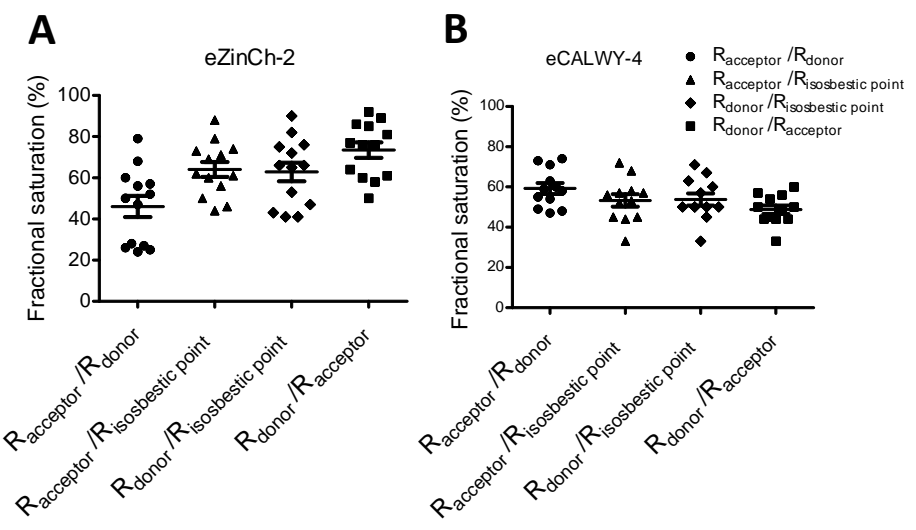

Figure S6: Fractional saturation of eZinCh-2 (A) and eCALWY-4 (B) in single HeLa cells as determined based on four different ratios. For each sensor the response of HeLa cells to the addition of $50 \mu \mathrm{M}$ TPEN, followed by excess $\mathrm{Zn}^{2+}$ and pyrithione $(100 \mu \mathrm{M} \mathrm{ZnCl} / 5 \mu \mathrm{M}$ pyrithione), was monitored by plotting four different emission ratios, acceptor/donor, donor/acceptor, acceptor/isosbestic point and donor/isosbestic point. The fractional saturation was determined per cell based on the emission ratio at the start of the experiment $\left(R_{\text {start }}\right)$, the emission ratio in the presence of TPEN $\left(\mathrm{R}_{0 \%}\right)$ and the emission ratio in the presence of excess $\mathrm{Zn}^{2+}\left(\mathrm{R}_{100 \%}\right)$ using equation 2. 
Table S1: Overview of FRET sensors used in this study.

\begin{tabular}{|c|c|c|c|c|}
\hline Sensor & Ligand & Ligand binding domains & $\begin{array}{l}\text { Fluorescent domains } \\
\text { (donor-acceptor) }\end{array}$ & $\begin{array}{l}\text { Emission ratio } \\
\text { (acceptor/donor) } \\
\text { empty->bound }\end{array}$ \\
\hline CALWY-4 ${ }^{1}$ & $\mathrm{Zn}^{2+}$ & ATOX1/WD4 & ECFP-EYFP & $1.05->0.9$ \\
\hline eCALWY-4 ${ }^{2}$ & $\mathrm{Zn}^{2+}$ & ATOX1/WD4 & Cerulean-Citrine & $4->2$ \\
\hline eZinCh- $2^{3}$ & $\mathrm{Zn}^{2+}$ & $\mathrm{Cys}_{2} \mathrm{His}_{2}$ & Cerulean-Citrine & $3->12$ \\
\hline Cer-L9-Cit-2His & $\mathrm{Zn}^{2+}$ & 2 His-tags & Cerulean-Citrine & $1.2->4$ \\
\hline MagFRET-1 ${ }^{4}$ & $\mathrm{Mg}^{2+}$ & HsCen3 & Cerulean-Citrine & $3.5->5$ \\
\hline Bas $-1^{5}$ & bile acids & $\begin{array}{l}\text { ligand binding domain of } \\
\text { FXR }\end{array}$ & Cerulean-Citrine & $4->2$ \\
\hline
\end{tabular}


Table S2: Overview of apparent $K_{d}$ values (in M) for $\mathrm{Zn}^{2+}$ binding determined for eZinCh-2 and eCALWY-4 at different $\mathrm{pH}$ 's based on 4 methods for emission ratio determination ${ }^{\mathrm{a}}$

\begin{tabular}{|l|l|l|l|l|}
\cline { 2 - 5 } \multicolumn{1}{c|}{} & Acceptor/donor & Donor/acceptor & Acceptor/isosbestic & Donor/isosbestic \\
\hline eZinCh-2 pH 6.0 & $2.6(0.4) \cdot 10^{-7}$ & $8.7(1.2) \cdot 10^{-8}$ & $1.5(0.2) \cdot 10^{-7}$ & $1.4(0.3) \cdot 10^{-7}$ \\
\hline eZinCh-2 pH 7.1 & $1.0(0.1) \cdot 10^{-9}$ & $1.9(0.4) \cdot 10^{-10}$ & $2.7(0.5) \cdot 10^{-10}$ & $3.4(0.6) \cdot 10^{-10}$ \\
\hline eZinCh-2 pH 8.0 & $5.0(1.7) \cdot 10^{-12}$ & $1.0(0.1) \cdot 10^{-12}$ & $1.4(0.2) \cdot 10^{-12}$ & $1.5(0.3) \cdot 10^{-12}$ \\
\hline eCALWY-4 pH 7.1 & $2.4(0.3) \cdot 10^{-10}$ & $5.0(0.8) \cdot 10^{-10}$ & $3.1(0.6) \cdot 10^{-10}$ & $4.2(0.5) \cdot 10^{-10}$ \\
\hline
\end{tabular}

a The number in parenthesis () represents $2 \times$ SD 
Table S3: Sensor occupancies of eZinCh-2 and eCALWY-4 when expressed in the cytosol of HeLa cells ${ }^{\mathrm{a}}$. The sensor occupancy was determined per cell based on the emission ratio at the start of the experiment $\left(\mathrm{R}_{\text {start }}\right)$, the emission ratio in the presence of TPEN $\left(\mathrm{R}_{0 \%}\right)$ and the emission ratio in the presence of excess $\mathrm{Zn}^{2+}\left(\mathrm{R}_{100 \%}\right) \mathrm{using}$ equation 2 . The standard deviation was determined using equation 2.

\begin{tabular}{|c|c|c|c|c|}
\cline { 2 - 5 } \multicolumn{1}{c|}{} & \multicolumn{4}{c|}{ Sensor occupancy (\%) } \\
\hline & Acceptor/donor & Donor/acceptor & Acceptor/isosbestic & Donor/isosbestic \\
\hline eZinCh-2 & $46 \pm 11$ & $73 \pm 8$ & $64 \pm 8$ & $63 \pm 10$ \\
\hline eCALWY-4 & $59 \pm 6$ & $49 \pm 5$ & $53 \pm 7$ & $54 \pm 7$ \\
\hline
\end{tabular}

a The numbers behind \pm sign represent $2 x$ SD 
Table S4: Free cytosolic $\mathrm{Zn}^{2+}$ concentrations (in $\mathrm{nM}$ ) based on all combinations of in vitro Kd values and sensor occupancies determined in situ for HeLa cells expressing eZinCh-2 (calculated using equation 2) ${ }^{\mathrm{a}}$

\begin{tabular}{|l|l|l|c|c|c|}
\hline \multirow{2}{*}{$\kappa_{d}(\mathrm{nM})$} & Occupancy & Acceptor/donor & Donor/acceptor & Acceptor/iso & Donor/iso \\
\cline { 3 - 6 } & & $0.46 \pm 0.11$ & $0.73 \pm 0.08$ & $0.64 \pm 0.08$ & $0.63 \pm 0.10$ \\
\hline Acceptor/donor & $1.0 \pm 0.10$ & $0.91 \pm 0.25$ & $2.8 \pm 0.40$ & $1.8 \pm 0.30$ & $1.9 \pm 0.40$ \\
\hline Donor/acceptor & $0.19 \pm 0.04$ & $0.16 \pm 0.05$ & $0.50 \pm 0.10$ & $0.33 \pm 0.08$ & $0.35 \pm 0.09$ \\
\hline Acceptor/iso & $0.27 \pm 0.05$ & $0.24 \pm 0.07$ & $0.72 \pm 0.20$ & $0.47 \pm 0.10$ & $0.50 \pm 0.10$ \\
\hline Donor/iso & $0.34 \pm 0.06$ & $0.30 \pm 0.09$ & $0.92 \pm 0.20$ & $0.60 \pm 0.10$ & $0.63 \pm 0.10$ \\
\hline
\end{tabular}

a SD was calculated from the error propagation rule for multiplication, equation 2

The SD of the calculated free cytosolic $\mathrm{Zn}^{2+}$ concentration was calculated using the error propagation rule for multiplication, equation 2:

$$
S_{u}=U \cdot \sqrt{\frac{s_{x}^{2}}{x^{2}}+\frac{s_{y}^{2}}{y^{2}}}
$$

Here, $\mathrm{U}$ is the free $\mathrm{Zn}^{2+}$ concentration, $\mathrm{S}_{\mathrm{u}}$ the standard deviation of this free $\mathrm{Zn}^{2+}$ concentration, $\mathrm{x}$ is the in vitro determined $K_{d}$ value and $\mathrm{S}_{\mathrm{x}}$ the standard deviation of this $K_{d}$ value. $\mathrm{Y}$ is the sensor occupancy and $\mathrm{S}_{\mathrm{y}}$ the standard deviation of this occupancy. 
Table S5: Free $\mathrm{Zn}^{2+}$ concentrations in various buffering systems at $\mathrm{pH} 6.0,20{ }^{\circ} \mathrm{C}$.

\begin{tabular}{cccccccccc}
\hline $\begin{array}{c}\text { Buffering } \\
\text { system }\end{array}$ & $\begin{array}{c}0.1 \mathrm{mM} \\
\mathrm{Zn}^{2+}\end{array}$ & $\begin{array}{c}0.2 \mathrm{mM} \\
\mathrm{Zn}^{2+}\end{array}$ & $\begin{array}{c}0.3 \mathrm{mM} \\
\mathrm{Zn}^{2+}\end{array}$ & $\begin{array}{c}0.4 \mathrm{mM} \\
\mathrm{Zn}^{2+}\end{array}$ & $\begin{array}{c}0.5 \mathrm{mM} \\
\mathrm{Zn}^{2+}\end{array}$ & $\begin{array}{c}0.6 \mathrm{mM} \\
\mathrm{Zn}^{2+}\end{array}$ & $\begin{array}{c}0.7 \mathrm{mM} \\
\mathrm{Zn}^{2+}\end{array}$ & $\begin{array}{c}0.8 \mathrm{mM} \\
\mathrm{Zn}^{2+}\end{array}$ & $\begin{array}{c}0.9 \mathrm{mM} \\
\mathrm{Zn}^{2+}\end{array}$ \\
\hline $1 \mathrm{mM}$ NTA & $1.59 \cdot 10^{-8}$ & $3.57 \cdot 10^{-8}$ & $6.12 \cdot 10^{-8}$ & $9.52 \cdot 10^{-8}$ & $1.43 \cdot 10^{-7}$ & $2.14 \cdot 10^{-7}$ & $3.3 \cdot 10^{-7}$ & $5.7 \cdot 10^{-7}$ & $1.27 \cdot 10^{-6}$ \\
$1 \mathrm{mM}$ EGTA & $7.77 \cdot 10^{-8}$ & $1.75 \cdot 10^{-7}$ & $3.0 \cdot 10^{-7}$ & $4.66 \cdot 10^{-7}$ & $6.98 \cdot 10^{-7}$ & $1.04 \cdot 10^{-6}$ & $1.62 \cdot 10^{-6}$ & $2.76 \cdot 10^{-6}$ & $5.93 \cdot 10^{-6}$ \\
$5 \mathrm{mM}$ EGTA & $1.42 \cdot 10^{-8}$ & $2.92 \cdot 10^{-8}$ & $4.47 \cdot 10^{-8}$ & $6.09 \cdot 10^{-8}$ & $7.78 \cdot 10^{-8}$ & $9.54 \cdot 10^{-8}$ & $1.13 \cdot 10^{-7}$ & $1.33 \cdot 10^{-7}$ & $1.54 \cdot 10^{-7}$ \\
$1 \mathrm{mM}$ HEDTA & $3.31 \cdot 10^{-12}$ & $7.45 \cdot 10^{-12}$ & $1.27 \cdot 10^{-11}$ & $1.99 \cdot 10^{-11}$ & $2.98 \cdot 10^{-11}$ & $4.47 \cdot 10^{-11}$ & $6.96 \cdot 10^{-11}$ & $1.19 \cdot 10^{-10}$ & $2.69 \cdot 10^{-10}$ \\
\hline
\end{tabular}

Table S6: Free $\mathrm{Zn}^{2+}$ concentrations in various buffering systems at $\mathrm{pH} 7.1,20{ }^{\circ} \mathrm{C}$.

\begin{tabular}{cccccccccc}
\hline $\begin{array}{c}\text { Buffering } \\
\text { system }\end{array}$ & $\begin{array}{c}0.1 \mathrm{mM} \\
\mathrm{Zn}^{2+}\end{array}$ & $\begin{array}{c}0.2 \mathrm{mM} \\
\mathrm{Zn}^{2+}\end{array}$ & $\begin{array}{c}0.3 \mathrm{mM} \\
\mathrm{Zn}^{2+}\end{array}$ & $\begin{array}{c}0.4 \mathrm{mM} \\
\mathrm{Zn}^{2+}\end{array}$ & $\begin{array}{c}0.5 \mathrm{mM} \\
\mathrm{Zn}^{2+}\end{array}$ & $\begin{array}{c}0.6 \mathrm{mM} \\
\mathrm{Zn}^{2+}\end{array}$ & $\begin{array}{c}0.7 \mathrm{mM} \\
\mathrm{Zn}^{2+}\end{array}$ & $\begin{array}{c}0.8 \mathrm{mM} \\
\mathrm{Zn}^{2+}\end{array}$ & $\begin{array}{c}0.9 \mathrm{mM} \\
\mathrm{Zn}^{2+}\end{array}$ \\
\hline $1 \mathrm{mM}$ NTA & $1.26 \cdot 10^{-9}$ & $2.84 \cdot 10^{-9}$ & $4.87 \cdot 10^{-9}$ & $7.58 \cdot 10^{-9}$ & $1.13 \cdot 10^{-8}$ & $1.7 \cdot 10^{-8}$ & $2.65 \cdot 10^{-8}$ & $4.55 \cdot 10^{-8}$ & $1.02 \cdot 10^{-7}$ \\
$1 \mathrm{mM}$ EGTA & $5.5 \cdot 10^{-10}$ & $1.2 \cdot 10^{-9}$ & $2.1 \cdot 10^{-9}$ & $3.3 \cdot 10^{-9}$ & $4.9 \cdot 10^{-9}$ & $7.4 \cdot 10^{-9}$ & $1.2 \cdot 10^{-8}$ & $2.0 \cdot 10^{-8}$ & $4.5 \cdot 10^{-8}$ \\
$5 \mathrm{mM}$ EGTA & $1.10 \cdot 10^{-10}$ & $2.06 \cdot 10^{-10}$ & $3.16 \cdot 10^{-10}$ & $4.30 \cdot 10^{-10}$ & $5.49 \cdot 10^{-10}$ & $6.74 \cdot 10^{-10}$ & $8.05 \cdot 10^{-10}$ & $9.42 \cdot 10^{-10}$ & $1.08 \cdot 10^{-9}$ \\
$1 \mathrm{mM}$ HEDTA & $2.02 \cdot 10^{-13}$ & $4.54 \cdot 10^{-13}$ & $7.79 \cdot 10^{-13}$ & $1.21 \cdot 10^{-12}$ & $1.82 \cdot 10^{-12}$ & $2.73 \cdot 10^{-12}$ & $4.25 \cdot 10^{-12}$ & $7.28 \cdot 10^{-12}$ & $1.64 \cdot 10^{-11}$ \\
\hline
\end{tabular}

Table S7: Free $\mathrm{Zn}^{2+}$ concentrations in various buffering systems at $\mathrm{pH} 8.0,20{ }^{\circ} \mathrm{C}$.

\begin{tabular}{cccccccccc}
\hline Buffering & $0.1 \mathrm{mM}$ & $0.2 \mathrm{mM}$ & $0.3 \mathrm{mM}$ & $0.4 \mathrm{mM}$ & $0.5 \mathrm{mM}$ & $0.6 \mathrm{mM}$ & $0.7 \mathrm{mM}$ & $0.8 \mathrm{mM}$ & $0.9 \mathrm{mM}$ \\
\multicolumn{1}{c}{ system } & $\mathrm{Zn}^{2+}$ & $\mathrm{Zn}^{2+}$ & $\mathrm{Zn}^{2+}$ & $\mathrm{Zn}^{2+}$ & $\mathrm{Zn}^{2+}$ & $\mathrm{Zn}^{2+}$ & $\mathrm{Zn}^{2+}$ & $\mathrm{Zn}^{2+}$ & $\mathrm{Zn}^{2+}$ \\
\hline 1 mM NTA & $1.61 \cdot 10^{-10}$ & $3.62 \cdot 10^{-10}$ & $6.21 \cdot 10^{-10}$ & $9.66 \cdot 10^{-10}$ & $1.44 \cdot 10^{-9}$ & $2.17 \cdot 10^{-9}$ & $3.38 \cdot 10^{-9}$ & $5.81 \cdot 10^{-9}$ & $1.3 \cdot 10^{-8}$ \\
$1 \mathrm{mM}$ EGTA & $9.61 \cdot 10^{-12}$ & $2.16 \cdot 10^{-11}$ & $3.71 \cdot 10^{-11}$ & $5.77 \cdot 10^{-11}$ & $8.65 \cdot 10^{-11}$ & $1.3 \cdot 10^{-11}$ & $2.02 \cdot 10^{-10}$ & $3.46 \cdot 10^{-10}$ & $7.82 \cdot 10^{-10}$ \\
1 mM HEDTA & $2.5 \cdot 10^{-14}$ & $5.63 \cdot 10^{-14}$ & $9.66 \cdot 10^{-14}$ & $1.5 \cdot 10^{-13}$ & $2.25 \cdot 10^{-13}$ & $3.38 \cdot 10^{-13}$ & $5.26 \cdot 10^{-13}$ & $9.03 \cdot 10^{-13}$ & $2.04 \cdot 10^{-12}$ \\
\hline
\end{tabular}

\section{References}

[1] van Dongen, E. M., Evers, T. H., Dekkers, L. M., Meijer, E. W., Klomp, L. W., Merkx, M. Variation of linker length in ratiometric fluorescent sensor proteins allows rational tuning of $\mathrm{Zn}$ (II) affinity in the picomolar to femtomolar range, J Am Chem Soc 2007, 129, 3494-3495.

[2] Vinkenborg, J. L., Nicolson, T. J., Bellomo, E. A., Koay, M. S., Rutter, G. A., Merkx, M. Genetically encoded FRET sensors to Monitor intracellular $\mathrm{Zn}^{2+}$ homeostasis, Nat Methods 2009, 6, 737-740.

[3] Hessels, A. M., Chabosseau, P., Bakker, M. H., Engelen, W., Rutter, G. A., Taylor, K. M., and Merkx, M. (2015) eZinCh-2: A versatile, genetically encoded FRET sensor for cytosolic and intraorganelle $\mathrm{Zn}^{2+}$ imaging, ACS Chem Biol 2015, 10, $2126-2134$.

[4] Lindenburg, L. H., Vinkenborg, J. L., Oortwijn, J., Aper, S. J., Merkx, M. MagFRET: the first genetically encoded fluorescent $\mathrm{Mg}^{2+}$ sensor, PloS one 2013, 8, e82009.

[5] van der Velden, L. M., Golynskiy, M. V., Bijsmans, I. T., van Mil, S. W., Klomp, L. W., Merkx, M., van de Graaf, S. F. Monitoring bile acid transport in single living cells using a genetically encoded Forster resonance energy transfer sensor, Hepatology 2013, 57, 740-752 